\title{
Composted Materials on Florida Roadsides ${ }^{1}$
}

\author{
Grady L. Miller, Michael S. Harrell, Gerald Kidder, and Robert Black ${ }^{2}$
}

\section{Introduction}

This fact sheet gives a brief overview of a two-year project conducted by researchers of the University of Florida's Institute of Food and Agricultural Sciences (UF/IFAS) as part of contract WO\#7 with the Florida Department of Transportation (FDOT).

\section{Project Objectives}

- Provide fundamental information on use of composted yard waste to control erosion and facilitate turf establishment on steep roadside slopes.

- Determine the effectiveness of biosolids compost as a fertilizer for improving stands of poor roadside grass.

- Assist FDOT in establishing standards and specifications for using composts.

- Provide FDOT with educational and promotional material on using composts.

\section{Components of the Project}

- Field studies of composted yard waste effects on erosion control.

- Field studies on fertilizing roadside turf with biosolids compost.

- Drafting specifications for compost use on FDOT projects.

\section{Erosion Control Study}

The experiment involved the use of composted yard waste as a mulch on steep roadside slopes for slope stabilization and establishment of permanent turfgrass cover. The experiment was conducted at two locations in Florida during 2000 and 2001.

- The northern site was located near Crescent Beach, Florida at the intersection of SR 206 and I-95. Soils were disturbed material, with approximately $4 \%$ organic content, and greater than $95 \%$ medium sand. Slope of the mulch test plot area was approximately $26^{\circ}(50 \%)$. At initiation of the study, the turf stand covered approximately $45 \%$ of the area.

1. This document is ENH 872, one of a series of the Environmental Horticulture Department, Florida Cooperative Extension Service, Institute of Food and Agricultural Sciences, University of Florida. Original publication date October 1, 2002. Visit the EDIS Web Site at http://edis.ifas.ufl.edu.

2. Grady L. Miller, Associate Professor; Michael S. Harrell, Graduate Assistant; Robert J. Black, Associate Professor, Environmental Horticulture Department, Gerald Kidder, Professor, Soil and Water Science Department, Institute of Food and Agricultural Science, University of Florida, Gainesville, FL 32611.

The Institute of Food and Agricultural Sciences is an equal opportunity/affirmative action employer authorized to provide research, educational information and other services only to individuals and institutions that function without regard to race, color, sex, age, handicap, or national origin. For information on obtaining other extension publications, contact your county Cooperative Extension Service office. Florida Cooperative Extension Service/Institute of Food and Agricultural Sciences/University of Florida/Christine Taylor Waddill, Dean. 
- The central site was located near Kissimmee, Florida at the intersection of US 27 and US 192. Soils were typical disturbed material found on road shoulders, with less than $1 \%$ organic matter and greater than $80 \%$ medium sand. Slope of the test plot area was approximately $12^{\circ}(21 \%)$. At initiation of the study, the turf stand was less than $20 \%$ of the area.

- Treatments consisted of mulch rates of 5 and 10 cm thick, seeded with 110 or $220 \mathrm{~kg} \mathrm{ha}^{-1} 80: 20$ bahiagrass:bermudagrass seed mix by weight, ground cover (Asiatic jasmine), straw erosion control mats (central site), and bahiagrass sod (central site). Erosion at the northern site was too severe to allow proper installation of the control mat or sod treatments.

\section{Fertilization Study}

A second experiment used biosolids compost as a fertilizer on existing thin stands of bahiagrass and bermudagrass at the two locations. Treatments consisted of composted biosolids at $0,20,40$, and 60 $\mathrm{Mg} \mathrm{ha}^{-1}$, and ammonium nitrate fertilizer at $98 \mathrm{~kg}$ $\mathrm{ha}^{-1}$ applied in late spring. A second application was made the following spring.

\section{Major Findings of the Project}

\section{Erosion Control Study}

- Composted yard waste mulch can effectively control erosion but does not necessarily facilitate the growth and establishment of turfgrass or other vegetation.

- It can provide slope stability for periods of at least 18 months and probably longer with or without vegetative growth.

- At the central site, lack of sufficient rainfall severely limited establishment of vegetation in compost-mulch-treated plots. At this location, sod and erosion mat treatments had greater turfgrass and vegetative cover, but all treatments effectively controlled erosion for the duration of the study.

- At the north site, compost mulch plots had total vegetation and turfgrass cover equal to or better than bare soil plots. Given the level of maintenance and watering, nearly all of the ground cover plants died.

\section{Fertilization Study}

- Composted biosolids materials provided greater vegetative cover when used as a topdressing than did a soluble fertilizer or no fertilizer at all the first year. The influence was not as great the second year when the materials were applied to a soil with approximately $4 \%$ organic matter.

Observations suggest that adequacy of water has a greater impact on turf establishment than nutrient addition and that infrequent mowing contributed to high weed populations, which may have reduced overall turf cover. 